\title{
JEAN RHYS: THE WRITINGS OF A WOMAN TOUCHED BY THE BRITISH EMPIRE
}

\author{
Francisco Javier Gil JaCinTo \\ Universidad de Sevilla \\ masefo@yahoo.es
}

\begin{abstract}
The starting point of this essay is the assumption that The British Empire, while it lasted, but also after its collapse, produced literature extolling its virtues and faults, which influenced some English authors in favour of or against colonialism. Along with these authors it is necessary to consider those born in the British colonies. Some of whom, without dealing with the subject head on showed in their work the less amiable face of The Empire, and the consequences that this had on the lives of its citizens. A representative case is the Dominican writer Jean Rhys. Although her novels and short stories resist labels of race and gender, it is worth considering to what extent her colonial upbringing marked her life as a creole and a woman. To illustrate this impact, we look at one of her novels and analyse in detail her last collection of short stories.
\end{abstract}

Keywords: Jean Rhys, British Empire, Creole, colonialism, West Indies, gender. 


\title{
JEAN RHYS: LA OBRA DE UNA MUJER TOCADA POR EL IMPERIO BRITÁNICO
}

\begin{abstract}
RESUMEN. El punto de partida de este trabajo es la asunción de que el Imperio Británico, mientras duró e incluso tras su desmoronamiento, produjo una literatura específica que permitió a una serie de escritores ingleses manifestarse a favor o en contra del colonialismo. Pero, junto a ese grupo de autores está también el de los nacidos en los territorios ocupados, los cuales, sin escribir directamente sobre el tema, mostraron en sus obras la cara menos amable del Imperio y las consecuencias para sus súbditos. Un caso representativo es el de la escritora Jean Rhys, nacida en Dominica. Aunque sus novelas y relatos resisten las etiquetas basadas en la raza o el género, es necesario considerar en qué medida las prácticas coloniales marcaron su vida como mujer y criolla. Para mostrar dicho impacto nos detendremos en una de sus novelas y analizaremos de manera exhaustiva el último de sus libros de relatos.
\end{abstract}

Palabras clave: Jean Rhys, Imperio Británico, criollo, colonialismo, Indias Occidentales, género.

Received 25 February 2018

Revised version accepted 31 May 2019

Robert Giddings, when addressing the subject of imperialism and its relationship with literature, maintains that the Empire produced its own literary works. In order to have a better understanding of the texts published at that time, it is useful to refer to political and economic aspects of this period, since the race for colonies the consequential contact between "the advanced industrialized nations and undeveloped societies" was reflected in these publications (Giddings 1991: 1), referred to by Elleke Boehmer as colonialist writing: "the literature produced in and about the British Empire" (2005: 10).

Accordingly, if the British Empire generated a certain kind of literature, its collapse, after World War II, should have brought an end to colonial or imperialistic writing. However, John M. Mackenzie points out how the imperial myth of the past, incarnated in Lawrence, continued to live throughout the 1950s and grew in the 1960s and 1970s, producing many publications in praise of and debunking the hero. It also proves that a certain amount of colonial writing was published in Britain after the end of World War II that helped to keep imperialist beliefs alive, and Mackenzie suggests that "perhaps the Lawrence myth was ideal for a declining empire" (1991: 177). It seems that the line between colonial and post-colonial literature is not as clear-cut as Boehmer suggests. Thus, what allows, for instance, Luis de Juan to read two Roald Dahl's short stories, produced after the late 1940s, as colonialist literature is their distinctive feature of dealing with the encounter between the First World and the Third World (2017: 57). 
To these two assertions, the first, that colonialism produced a specific kind of literature, and the second, that it was still alive in the 70s, it is necessary to add a third. Colonialism also generated writers, usually born in the colonies, whose lives were marked by this circumstance long after the Empire was gone. That may have been reflected in their books even when the subject of Colonialism was not central to the story. That is why the Jean Rhys's short stories in Sleep it off Lady, the last collection to be published while she was still alive, and therefore, the most removed from times of Empire, can still be read as colonial literature. Adding the prefix post- to them seems irrelevant. The important fact here is that all of them were written by a West Indian woman trying to make a living in Europe.

In the same way, gender-based literary appraisal of these stories also seems redundant, since all her literary work revolves around women, or if we are to believe her biographer Carole Angier, around herself. Angier, in her introduction to her book Jean Rhys, states that "she explored her own age, its mood and changes, almost by accident. What she set out to explore were her own personal feelings" (Angier 1985: 18). Therefore, the novels of Jean Rhys were "necessarily autobiographical" (19), since she herself confessed: "I just wrote about what happened. Not that my books are entirely my life...but almost" (19). The autobiographical tone of her writings may have been brought about as described by Boehmer:

In writing, as many postcolonial women critics have by now recognised, women express their own reality, unsettle male-focused (and other exclusionary) narratives, and do question received notions of national character and experience. But writing is more than this, too. To write is not only to speak for one's place in the world. It is also to make one's own place and narrative, to tell the story of oneself, to create an identity. (Boehmer 2009: 94)

And her story was that of a Creole woman struggling to make a living in Europe, and in an England that she never considered her own country. This perception of herself as not British can be observed in her fictional writing, and not only in her already mentioned short stories, but in her five novels. Good Morning, Midnight like the four previous novels, whilst continuing to be fiction, contains so many biographical details that readers tend to take them as a testimony, and identify the author with the character. In this case, we have Sasha Jansen who (like Jean Rhys, born Ella Gwendolen Rees Williams) has changed her name, lives in Paris sleeping in cheap pensions, surviving as a model or doing other menial jobs, and spending most of her time in cafes and restaurants. The most significant thing is that Sasha's nationality is never revealed, even though her French patronne calls her L' Anglaise (Rhys 1974: 79). The hotel owner is puzzled by what he finds written in Sasha's papers, and then asks her to use her nationality by marriage (14), without readers knowing which one it is. At this point in the novel we only know that she is living 
in London before she moves to the continent. We also learn soon that she can speak English with the boss from the London branch when he visits the shop in Paris, and that she "understand[s] French quite well", but that this is not her mother language (19). We presume that it must be English as she gives private English lessons later in the novel, but we are unsure since she says of her Russian pupil that he speaks English as well as she does (131).

Whatever the reason for that, we often see Sasha (or the third voice narrator) referring to English people as a different nationality. She alludes to some customers at the shops as "an old English woman and her daughter" (21), or to a colleague as "an English mannequin" (23). She also becomes surprised, and a little irritated, when a girl asks if she knows an old Englishwoman, assuming perhaps that she may be English herself: "No, I do not know her. Why should you imagine I know her?" (41). Nevertheless, the protagonist of Good Morning. Midnight seems to know English people first-hand, and she does not feel sympathy for them. She says of the English mannequin: "Kind, kind, and gentle is she - and that's another damned lie. But she is very beautiful -" (23); in the same fashion, when she is told that the English manager is "the real English type. Very nice, very, very chic, the real English type", she can't help thinking, "Oh, my God. I know what these people mean when they say the real English type", and she doesn't want to know him (19). Later in the novel, after having been compassionate with a Spanish-American eager to have a conversation with someone, she thinks: "I had meant to get this man to talk to me, and then be so devastatingly English that perhaps I should manage to hurt him a little in return for all the many times I've been hurt" (73).

We do not know whether those who hurt her were English or not, but she has never felt loved by the English, otherwise she would not state to her Moroccan gigolo friend that "love is a stern virtue in England. [...] The indecent necessity - and who would spend money or time on the indecent necessity?... We have our ration of rose-leaves, because rose-leaves are a gentle laxative" (157). This unusual "we" to refer to herself as English is soon contradicted: "We're on the wrong bed [...]. And with all our clothes on, too. Just like English people". At the end of the novel, we have not yet learned where Sasha Jensen comes from, only that, like Jean Rhys, she is not very keen on English people, so it is not a surprise that when her Russian student "makes a little speech about English hypocrisy", she adds "preaching to the converted" (132). It is her gigolo friend who has an explanation for her lack of sympathy for English people when he tells her: "You talk like that because you're a woman, and everybody knows that England isn't a woman's country. You know the proverb - unhappy as a dog in Turkey or a woman in England? - (157)". Then, she reveals in her thoughts 
what she doesn't dare say out loud to her friend who wants to go to England: "He'll find out that he will be up against racial, not sexual, characteristics" (157). For the same reason when her Russian pupil asks her if she thinks that English people will like him, she answers aloud without hesitation: "Yes, I'm certain they will. (I've only to look at you to know that they'll like you in England.)" (139). He is a White Caucasian escaping from the Soviets and not a non-white escaping from poverty.

Judith L. Raiskin in her edition of Wide Sargasso Sea includes a letter by Jean Rhys written in 1949 to Peggy Kirkcaldy in which we can see how writing was just a means to escape poverty, not a choice, just another consequence of colonialism: "I never wanted to write. I wished to be happy and peaceful and obscure. I was dragged into writing by a series of coincidences - Mrs. Adam, Ford, Paris - need for money" (1999: 133). Related to her monetary preoccupations, Raiskin also rescued an unpublished Rhys manuscript, "The Bible is Modern", in which she writes that "what is difficult for us black people to understand is the ingenious way they [Englishmen] set about making money out of God said 'Let there be Light'" (149). Then Raiskin adds in a foot note that, despite Jean Rhys identifying herself as a white Creole, "her self-identification here as a 'black' is a political stance to position her in opposition to the metropolitan colonizing culture" (149).

But whereas Jean Rhys's racial identification as a Creole, "who perceived herself to be, as a displaced colonial" (Raiskin 1999: ix), appears not to be problematic, it is a little more difficult to consider her a Creole writer. Veronica Marie Gregg makes an attempt to give an answer to that question in Jean Rhys's Historical Imagination (1995), whose subtitle, Reading and Writing the Creole, seems to be a response to that inquiry. However, at the end of the book this critic only speaks about a not very precise "Creole mode of subjectivity" (197), through which, she had explained earlier, Jean Rhys managed to rewrite the West Indian history narrated by the dominant European, by means of invoking her West Indian identity to act as historiographer, and to claim "the right to imagine her own past [...] and to reinterpret the Caribbean as she knows it" (73), in accordance with the idea that "national identity rests on received images of national history and topography (Boehmer 2009: 94).

As we have seen, Jean Rhys's writings resist the narrow frame of race investigations as happened with attempts to classify her work as autobiographical, to make it the subject of colonialism and gender studies, or postmodernist and inter-textual perspectives. For this reason, the aim of this paper is not to label her final collection of short stories, Sleep it off Lady (1976), but to point out how any possible analysis of her work needs to be modulated according to the impact that the Empire had on her life, and thereafter on her literary production. 
Sleep it off Lady appeared in 1976, and yet ten of the sixteen stories in the book are set in the time in which they were written, others are set in the colonial period. Nevertheless, the shadow of Empire is long enough to cast a shadow on some of those stories apparently at a remove from colonialism. The first one "Pioneers, Oh, Pioneers", is set when "it was still the nineteenth century, November 1889" (Rhys 1979a: 11), and Dominica was one of the Caribbean islands ruled by the British Empire. Unlike its homonymous Walt Whitman poem first published in Leaves of Grass in 1865, and also almost homonymous Willa Cather's novel, $O$ Pioneers! (1913), Rhys's short history "Pioneers, Oh, Pioneers" does not celebrate the spirit of immigrant pioneers marching "so impatient, full of action, full of manly pride and friendship" (Whitman 1909: 223). Rather, it portrays the West Indian colonizers' struggle to subdue a wild land that never ceased to be remote and strange. At the turn of the nineteenth century Dominican settlers had to cope not just with the tropical weather, but also with the suffocating social and racial Victorian prejudices.

The final story of the book, "I Used to Live Here Once" stands as a confirmation that the European imperial dream had its moment, and then it had to pass. This brief description of what seems to be the return of the author's ghost to her native land shows the battered remains of the colonial period. The road, which she walks along now feeling extraordinarily happy, is "much wider than it used to be but the work had been done carelessly. The felled trees had not been cleared away and the bushes looked tramped" (Rhys 1979a: 175).

During the colonial period roads were inaugurated with much pomposity as a sign of the modernity and progress that would bring prosperity even to the remotest parts of the Empire. James B. Wolf in "Imperial Integration on Wheels: The Car, the British and the Cape-to-Cairo Route", takes a look at the writings of casual travellers in British Africa, which reveal their attitudes and responses to the nonWestern world. In this chapter, Wolf relates how for motorists, cars, as a Western invention, provide a sense of cultural security, and driving along the African roads had a sort of imperial glamour, which persisted well into the twentieth century (1991: 112-125). We have to assume then that, the so-called Imperial Road in the very centre of Dominica was expected to supply the same kind of feelings to the British visitors and it "was meant to attract young Englishmen with capital who would buy and develop property in the interior" (Rhys 1979a: 19). The opening of this road at the turn of the nineteenth century made accessible a fertile area that had long been unproductive. The hazardousness of the project is related by Peter Hulme in "Islands and roads: Hesketh Bell, Jean Rhys and Dominica's Imperial Road", where he relates that the road was never completed, despite the thousands of pounds committed for its construction, because of the bad condition 
of the forest, which increased the cost, and as a result sustained investment in the interior failed to arrive (2000: 29-33).

It was at that time of uncertainty for the colony, the last decade of the nineteenth century that Jean Rhys was born in 1890. Her father was an English doctor, and her mother a Creole or West Indian, whose family had had a great influence on the island for generations. Therefore, she must have been one of these children described in "I used to Live Here Once": very fair, "as Europeans born in the West Indies so often are, as if the white blood is asserting itself against the odds" (1979a: 176). Nevertheless, a quick look at the biographical reference of the Penguin edition of Sleep it off Lady is enough to reveal that her privileged position in the island does not prevent her, from living a rootless, wandering life, common to many people when she reached the metropolis, "she was sixteen and then drifted into a series of jobs - chorus girl, mannequin, artist's model - after her father died" (1). Then, she went to Paris, where the first of her three marriages collapsed and she began to write novels and short stories, whose alienated and stranded heroines seem to act as alter egos of the author.

She carried on doing this until her death. In "Overture and Beginner Please", another of the short stories includes in Sleep it off Lady, the autobiographical references are so explicit that it could be read as a chapter of her unfinished memories Smile Please: An Unfinished Biography. In the story, a West Indian girl is sent to Perse School in England, "because her [my] English aunt said it was a good school" (65), and after that, she enrols in the Academy of Dramatic Arts. Jean Rhys left Dominica at sixteen, like many privileged colonial children, to be educated in the metropolis. Most white Creoles considered themselves to be British, and England as their mother country. Therefore, when they sent their children to the land of their ancestors, they did not realize how traumatic this voyage was for most of them. But in fact, these young people, Jane included, must have shared the same thoughts as the protagonist: "What is going to become of me? Why I am here at all?" (70). The journey to England made by Rhys's fictional, and to some extent quite autobiographical character, exposes the cultural and emotional displacement of colonial children in a metropolis. The Caribbean girl dislikes the cold weather, and the sky "that was of the colour of no hope" (70). She describes the streets as hostile, and the buses as hateful, where she is "always squashed up against perfect strangers, millions of perfect strangers in this horrible place" (71). She is also afraid of appearing before the strange girls at the boarding school in a dress that she finds hideous, because she believes they are bound to dislike her. British people are perceived not as country fellows, but as strangers.

Apart from pursuing an education, natives from the colonies journeyed to the metropolis hoping for work. The heroine from "Overture and Beginner Please" 
needs to earn her own living in England. Her father's death makes it quite impossible for her mother to continue sending money to keep her at the theatrical school in London. She manages to stay in England as a chorus girl, which as her aunt says is "not much of a living" (76). Jean Rhys went through the same experience as her character. Therefore, she knew first-hand about the economic exploitation of displaced people. In the case of women this exploitation was also sexual. The Dominican girl of the story has no option but to join a cheap theatrical company, or marry a well-off man, who "may be a horrid boy, but he's got a lot of money" (76). It is almost impossible to refrain from making a comparison with Jean Rhys's own life.

Jean Rhys also exposes the sexual exploitation of the colonized woman in "On Not Shooting Sitting Birds". The protagonist is a lonely expatriate in Europe with only "a few acquaintances and no close friends" (89). She has also started to loosen her ties with the past, her memories from the Caribbean are vague or trivial or meaningless, as explained by Cristina Voicu:

The displacement and resettlement of Rhys's protagonists is condemned to
inbetween-ity. [...] Thus, the Caribbean islandscape becomes an illusory psychic
space made out of the flashbacks of second-hand memories.
In dealing with the loss of the Caribbean Landscape as homeland, Rhys's fiction
foreshadows the issues of homecomings and alienation experiences of the white
Creoles who oscillate between the lost ancestral culture, harsh poverty-stricken
inland societies and the hostile landscape of the metropolitan host cultures. (Voicu
2014: 35-36)

It is perhaps in reaction against such isolation that this protagonist starts "doing bold, risky, even outrageous things without hesitation or surprise" (89), like agreeing to have dinner with a man who smiles at her. So, they are, "seated at a table having dinner with a bedroom very obvious in the background"; and he is asking her "but you're a lady, aren't you?" (90) implying the opposite.

The vulnerability of colonial women to sexual abuse is denounced in another of the short stories of Sleep it off Lady. In "Good-bye Marcus, Good-bye Rose", the old Captain Cardew, while spending the winter in Jamaica with his wife seduces little Phoebe, who is only twelve. He thinks she will be soon old enough to have a lover. He physically abuses her in the Botanic Gardens, which evidences not only the lust of the wanton man, but also the indelicacy of exposing the girl to the gossip of the island. The story relates how the Captain darts his hand towards her, "dived inside her blouse and clamped itself around one small breast [...] when a couple came around the corner. Calmly, without hurry, he withdrew his hand" (26) although he was breathing very heavily. 
According to Boehmer, "the silenced and wounded body of the colonised is a pervasive figure in colonial and postcolonial discourses, although its relevance obviously shifts with the transition from colonial into postcolonial history" (2009: 127). This physical abuse practiced on the island by the white community towards women and coloured natives is exposed bluntly in "Fishy Waters". The story is set around the trial of a British workman, Jimmy Longa, accused of child-molesting and cruelty in the 1890s. He is found trying to saw a little girl, "one of the vagabond children who infect the streets of Roseau" (45) in two. The episode produces many arguments, gossip, news and letters to the local newspapers, which bring divergent points of view regarding colonists' behaviour on the island to the surface. A letter sent to the Dominican Herald, for instance, and signed Disgusted, states that there is "a certain class of person on this island, who seem to imagine that the colour of their skins enables them to behave like gods" (46), and these people resent that "they no longer have power over the bodies and minds of the blacks that they once had" (45-46). Disgusted is viewed as someone who tries to stir up racial hatred, whenever possible dragging in the horrors of the slave trade. Despite these disparate perceptions of the facts, the general opinion of the white islanders is that there will be no trouble for the attacker. As one of the characters in the story says: "Why should there be [trouble], Longa is a white man, not a black one" (48). At the end of the trial the magistrate cannot produce any direct evidence against Longa, who is just urged to leave the island in order to stop the gossip. Thus, the Government pays his passage to Southampton, in England. The girl that refused to say anything about what happened is sent to Santa Lucia with an old lady who has no children of her own. In this way, the case is happily settled, but the doubt remains at least for one of the islanders, who wonders if the reason for the Negro child's silence is "because she has either been persuaded or threatened- probably a bit of both - not to talk?" (55).

The whole episode of "Fishy Waters" shows the difficult position that women had to endure during the colonial period. This position was naturally harder for natives. The quest for identity latent in many of Jean Rhys's heroines does not include native women. The construction that the author makes of the black female identity has some of the clichés of the age of imperialism. In "Pioneers, Oh, Pioneers", black women are only described physically, as barefooted, wearing gaily striped turbans and high waisted dresses. In "Pioneers, Oh, Pioneers" the coloured girl that Mr. Ramage marries, Isla Harrison, is defined by her looks: "dressed up to the nines, smelt very strongly of cheap scent and talked loudly in an aggressive voice. No, she certainly wasn't a nice coloured girl" (15). In any case, native women are almost absent, or just depicted as maids in those short stories that are set in the West Indies. The colonial English community seems to 
have had trouble integrating coloured women into its circle. That must have been the reason why "the Ramages were lost to white society" (15), but the author does not make this point clear.

Jean Rhys's position regarding the colonialism practiced by the British in the West Indies is difficult to gauge. Peter Hulme points out that one of the stories to be included in Sleep It Off, Lady, a fictional version of her visit to Dominica in 1936, "The Imperial Road," was declined by the publisher "considering it to be too anti-negro in tone" (2000: 25). In "Black/White" from Smile Please, she relates how after trying to become friends with a coloured girl in the school convent, she is told "Oh, go away" which she recognized as hatred. After that, she writes: "I never tried to be friendly with any of the coloured girls again. I was polite and that was all" (Rhys 1979b: 47-50). The short story collection, Sleep it off Lady seems to be the work of a settler rather than an imperialist or anti-imperialist. In "Heat" the author relates the story of the volcano that destroyed Saint Pierre in Martinique in 1902. It "was a very wicked city. It had not only a theatre, but an opera house, which was probably wickeder still. Companies from Paris performed there (41)." The character telling the story resents that the English version of the eruption, discovered in an old pile of newspapers "said nothing about the opera house or the theatre which must have seemed to the English the height of frivolity on a Caribbean Island, and very little about its inhabitants" (41).

However, despite the displacement experienced by some of the Creole characters in the book, they are still the masters of the blacks on the island, and therefore Jean Rhys's writing also contributed to the production of the cultural representation of the Empire to English people. The short stories of Sleep it off Lady contain many allusions to Western Empires. Doctor Cox, for instance, reads The Times weekly edition in "Pioneers, Oh, Pioneers"; the lustful Captain Cardew of "Good-bye Marcus, Good-bye Rose", when young was a subaltern in India; Suzy, the demimonde girl of "Night Out 1923" listens to a java in the company of an Englishman; and the married Dutch man who goes to visit his former lover in Bristol in "Who Knows What's Up in the Attic" tells the woman how he was brought up in Indonesia by an uncle; then he comments: "I would be with you as often as I could. But you see my job. And there is my wife", which together with the "attic" of the title, conjures up the Caribbean woman Antoinette Cosway (or Bertha Mason) of Wide Sargasso Sea (1967), the most famous novel of the writer.

The author's longing for her native land expresses itself in small details in the stories set in the metropolis. "Kimora" describes a typical English dinner offered to Baron Mumntael, a naturalized Englishman, who exclaims as he enters his hosts' house: "What a typical interior"" (85). Toward the end of the afternoon, he catches sight of a picture of a naked man, palm trees, and a whale in a dark blue sea, 
which his hostess names "Paradise". Maybe that is just the idea that Europeans have of Paradise. The same as the lady in "Rapunzel, Rapunzel", when she looks out of the hospital window, she sees "instead of the London plane trees, it was an Arab village or her [my] idea of one, small white houses clustered together on a hill" (139).

That idealistic representation of another side of the Empire causes Edward W. Said to call chapter II of his Culture and Imperialism "Consolidated Vision". There he explains how the colonies provided exotic settings for novels and operas that affected the aesthetic trends in the metropolis often compatible with the colonist ideology, which doesn't see contradiction in the fact that Imperialism was based on the practice of taking over control of a territory (Said 1993: 62-185). This set of beliefs around the Empire was fortified by assumptions concerning the superiority of the Caucasian Whites over any other race, and Jean Rhys raises the subject with irony when the femme du monde of "The Chevalier of the Place Blanche" mocks her interlocutor asking if "the modern Apache" are still brutal and reckless? (121).

This unfavourable image of the Indians, according to Kathryn Z. DerounianStodola, was created to justify White society's lust for more territories. The new literary genre showing the brutality and the cruelty of the Native Americans served to spread propaganda against them among the white Americans emigrating to the West (1993: 22-23), and although the captivity stories are no longer in fashion, the scenes of gangs of violent Indians ransacking a caravan of peaceful pioneers is familiar to anyone that has watched a Western movie.

The division between Whites and any other ethnic group is noticeable throughout all the stories of Sleep it off Lady, not just those set in the colonies. "The Insect World" takes place in London during the Blitz, and one of its protagonists, Audrey, is reading a book "set in the tropics", in which "there was this horrible girl whom the hero simply has to make love to, though he didn't really want to". It is not said what race she is, but when Audrey is telling the story of the book to her friend she makes a contrast between "the lovely, cold English girl" (127) that turned the hero down when she heard about the affair with the other woman. Also, the natives, she carries on, were surly and stupid, and "they became cruel, so horribly cruel, you wouldn't believe...." (128). In the short story, we do not know where Audrey and her friends come from, but they always speak about English people among them: "English People always mix up tropical places. My dear, I met a girl the other day who thought Moscow was the capital of India!" Then she added: "I think it's dangerous to be as ignorant as that, don't you?" (130). We assume Jean Rhys, is speaking through Audrey's mouth, about the incomprehension, as a West Indian Creole, she found in England all her life, something which is showed in Sleep it off Lady. 
The collection of short stories in Sleep it off Lady stretches from the very end of the nineteenth century to the 1970s. These dates coincide with the beginning of the colonial crisis in Dominica, when the effects of the failure of the Imperial Road to attract new investors to the island was being felt, and with the final independence of Dominica from the West Indies Federation in 1978. The dates of Jane Rhys's birth and death are almost the same, and her personal life seems to have been overshadowed by the decline of the colonial experience, which Judith Raiskin summarizes as "a lifetime of writing and struggling to write while suffering the miseries of poverty, isolation, and illness" (1999: ix). And after that, the big success of Wide Sargasso Sea in 1996, the WH Smith Literary Award for authors of the British Commonwealth in recognition for her contribution to English literature, the re-edition of all her novels, and the Order of the British Empire (O.B.E) at the late age of 88. She now had fame and money, but maybe, as she has been reported to have said: "it has come too late" (McDowell 2009).

Jean Rhys would have imagined quite a different end for herself, in any of the remote English villages where she had been secluded for decades, probably something similar to Mrs. Verney's death in "Sleep it off Lady". This is the penultimate short story of the book, and the one that gives its name to the whole collection. Although for some critics like Angier (1985) and Gregg (1995), it is in the last story, "I used to Live Here Once", where Jean Rhys has a vision of herself as a ghost returning to Dominica. However, it is in "Sleep it off Lady" where the old protagonist, "certainly over seventy", as an echo of the author, confesses to a friend "I have been thinking a great deal about death lately" (159). She has been dreaming about it as well, and in her dreams, she has seen the shed, which becomes an obsession, and is haunting her throughout the story "changing its shape and becoming a very smart, shiny, dark blue coffin picked out in white" (159). Finally, she dies of shock, cold and alone in the hospital without recovering consciousness after falling on the ground near the shed one evening. Little Deena, a girl of twelve that used to spy on Miss Verney's, had refused to ask her mother for help. Instead she told her: "She doesn't like you and doesn't want to have anything with you. She hates stuck up people. Everybody knows that you shut yourself up to get drunk". And then, as she continues scolding her, the reader learns where the title of the short story came from: "People can hear you falling about, 'she ought to take more water with it', my mum says, Sleep it off lady" (159). It is the postman who finds her the following morning, lifts and takes her inside the house and tries to force her to drink some whisky from an open bottle before calling for an ambulance.

We know very little about this Mrs. Verney: she is old, she drinks, she comes from somewhere else, she lives alone and without a telephone in a cottage in 
the least prosperous part of the village. She thinks that children can be cruel and merciless, and that other women "stared at her with curiosity and some disapproval, she couldn't help feeling" (168), and she is thinking about death and is haunted by obsessions. This is how Jean Rhys is described by Carole Angier in parts five and six of her biography, especially before the success of Wide Sargasso Sea. Thus, if we believe the Carole Angier introduction, when she quotes Jean Rhys, "Not that my books are entirely my life...but almost", she has to be Miss Verney. But surprisingly in this story, there is no reference to the colonial period or the Empire: it is not needed. It is enough to show the havoc it caused its children, specially to these women who moved to the metropolis where they were rejected by a prejudiced White society, which saw them as second-class citizens with dubious morals. These prejudices condemned creole women, in many cases in order to survive, to engage in menial or degrading jobs and deal with unscrupulous people.

\section{REFERENCES}

Angier, C. 1985. Jean Rhys. New York: Viking.

Boehmer, E. 2005. Colonial \& Postcolonial Literature. Oxford: Oxford University Press.

Boehmer, E. 2009. Stories of Women: Gender and Narrative in the Postcolonial Nation. Manchester: Manchester University Press University Press.

Cather, W. 1941 (1913). O Pioneers! Boston: Houghton Mifflin Company, 1941.

de Juan, L. 2017. "Roald Dahhl's Look at the British Empire through his two Short Stories "Poison" and "Man from the South"”. Journal of English Studies 15: 5370. http://doi.org/10.18172/jes.3266.

Derounian-Stodola, K. 1993. The Indian Captivity Narrative 1550-1900. New York: Twayne Publishers.

Giddings, R. 1991. Literature and Imperialism. New York: St. Martin's Press.

Greeg, V. M, 1995. Jean Rhys. Historical Imagination. Reading E Writing the Creole. Chapel Hill: The University of North Carolina Press, 1995.

Hulme, P. 2000. "Islands and roads: Hesketh Bell, Jean Rhys and Dominica's Imperial Road.” The Jean Rhys Review 11: 23-51. <http://repository.essex.ac.uk/ $\mathrm{id} /$ eprint/2827>.

Mackenzie, J. M. 1991. "T. E. Lawrence: The Myth and the Message". Literature and Imperialism. Ed. R. Giddings. New York: St. Martin's Press: 150-181.

McDowell, L. 2009. "Jean Rhys: Prostitution, alcoholism and the mad woman in the attic". Independent. 3 May. <http://www.independent.co.uk/arts-entertainment/ 
books/features/jean-rhys-prostitution-alcoholism-and-the-mad-woman-in-theattic-1676252.html>

Raiskin, J. L. Ed. 1999. Wide Sargasso Sea. Jean Rhys. New York: W. W. Norton \& Company.

Rhys, J. 1974 (1939). Good Morning. Midnight. New York: Vintage Books.

Rhys, J. 1979a (1976). Sleep It Off Lady. Harmondsworth, Middlesex: Penguin Books.

Rhys, J. 1979b. Smile Please: An Unfinished Autobiography. New York: Harper and Row.

Said, E. 1993. Culture and Imperialism. New York: Vintage Books.

Voicu, C. G. 2014. Exploring cultural identities in Jean Rhys' fiction. Warsaw; Berlin: De Gruyter Open.

Whitman, W. 1909 (1855). Leaves of Grass. London: Cassel and Company.

Wolf, J. B. 1991. "Imperial Integration on Wheels: The car, the British and the Cape-to Cairo Route". Literature and Imperialism. Ed. R. Giddings. New York: St. Martin's Press. 112-127. 